INTERDISCIPLINARIA ARCHAEOLOGICA NATURAL SCIENCES IN ARCHAEOLOGY

\title{
Interpretive and Analytical Approaches to Aerial Survey in Archaeology
}

\author{
Ladislav Šmejda ${ }^{a^{*}}$ \\ ${ }^{a}$ Czech University of Life Sciences Prague, Department of Ecology, Kamýcká 129, 16521 Praha 6 - Suchdol, Czech Republic
}

\section{A RTICLE INFO}

\section{Article history:}

Received: $13^{\text {th }}$ October 2016

Accepted: $19^{\text {th }}$ June 2017

DOI: http://dx.doi.org/ 10.24916/iansa.2017.1.6

Key words:

aerial prospecting

sampling strategy

verticals and obliques

methodology

\begin{abstract}
$A B S T R A C T$
This article discusses two contrasting approaches to archaeological survey using aerial reconnaissance. A more traditional strategy is to look for interesting spots in the landscape with a highly concentrated archaeological record. These are usually called "sites". This concept is still used in everyday practice, despite its long-standing problematic character. The opposing approach divides the studied region into analytical units, which are sampled for evidence in a standardized manner and only then is the collected information subsequently interpreted. Varying densities of recorded facts across space are now studied rather than the binary categories of "on-site" and "off-site". In Czech archaeology, this operational difference has often been classified as the "synthesizing" vs. "analytical" research methodology. This debate has been ongoing for quite some time in the context of field-walking and surface collection of archaeological finds. This text examines an analogous problem in the field of aerial survey, where it seems to be closely connected to another long-standing methodological and terminological discussion: the comparative usefulness of "oblique vs. vertical" aerial photography.
\end{abstract}

\section{Introduction}

The concept of an analytical approach to archaeological surface collection has been associated with processual archaeology and its emphasis on sampling and the quantitative aspects of the archaeological record (Redman 1987; Schiffer et al. 1978). These research strategies have been systematically rethought, enriched with a number of new observations and improvements and, most importantly, brought into practice in central European archaeology by M. Kuna (e.g. 1994; 1998; 2000; 2004). This has occurred in such a convincing manner that within one or two decades they have become an integral part of the archaeological methodology. Given the statistical evaluation of data and the study of their spatial properties in Geographical Information Systems (GIS), the discipline has gained a highly effective tool which has significantly advanced our understanding of the past (Gojda 2004a; Neustupný 1998; Neustupný, Venclová 2000; Smrž et al. 2011; Šmejda 2003).

The core of this article, which entirely subscribes to the inspiration mentioned above, considers the idea that aerial

*Corresponding author. E-mail: smejda@fzp.czu.cz survey in archaeology can be understood in terms of both an analytical and synthesizing (interpretive) methodology, similar to that of surface survey by fieldwalking (Šmejda 2009). In an analogous way to the development of the techniques of surface collection of artefacts, in the field of aerial survey, we can also observe a movement from the effort to identify individual spots of interest in the landscape to a systematic study of entire landscape transects. In this more recent approach, space is understood as a continuum that is sampled in a certain controlled routine, the results and interpretations being gained later, independently of the process of data collection. The former approach, the discovery of new "sites" through data collection, is a synthesizing method because the interpretation of empirical observations is conducted immediately during field-walking, while the latter is an analytical approach because only the analysis (analytical decomposition) of the area being investigated is conducted in the field.

In order to discuss these strategies in the context of aerial reconnaissance, it is first necessary to compare the properties of the two elementary categories of aerial photographs, i.e. so-called "oblique" and "vertical" photographs (Doneus 2000). They have traditionally been perceived as standing 
in mutual opposition to each other as regards their technical parameters and practical utility. The aim of this paper is to evaluate oblique and vertical aerial photographs in terms of the two above-mentioned survey strategies: synthesizing and analytical approach.

\section{Oblique and vertical aerial photographs}

As their names suggest, the main criteria for distinguishing between vertical and oblique photographs is the orientation of the camera at the moment when the photograph is taken. Verticals are produced when the camera's optical axis is oriented downwards, perpendicular to the horizontal plane. For practical reasons, a small deviation (usually less than 3 degrees) of the optical axis from the plumb line is generally tolerated. Obliques are captured by cameras that

A

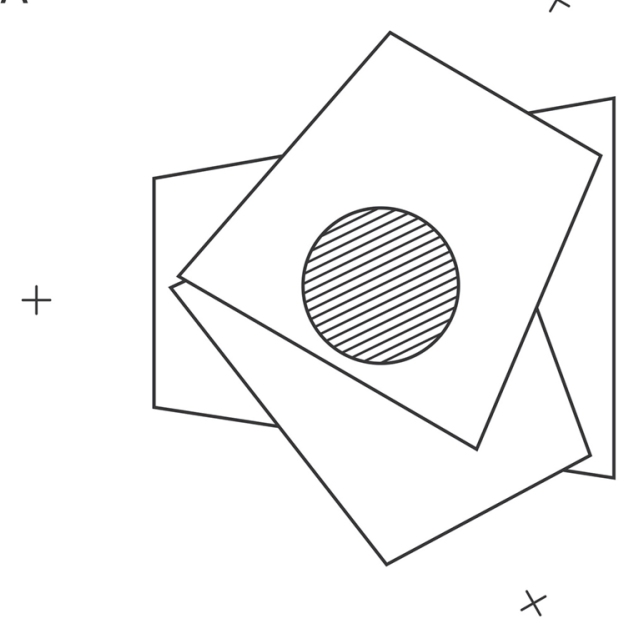

B

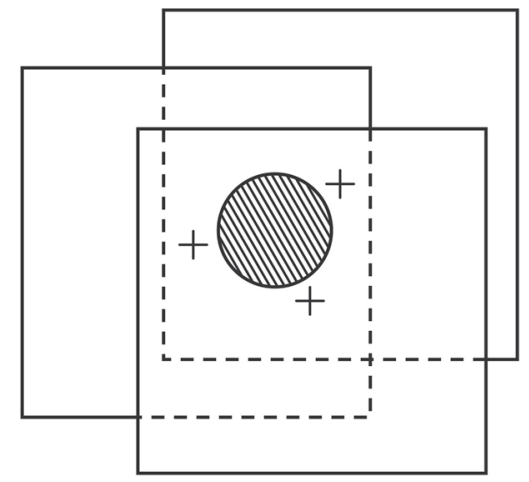

Figure 1. Footprints of oblique (A) and vertical (B) aerial photographs covering an archaeological site. The crosses mark the nadirs of individual photographs, i.e. the points directly below the camera positions. Note that they are located outside the covered area in the case of obliques, while they coincide with the centres of vertical photos (after Hampton1978, Figure 9). are tilted significantly from the vertical. We speak about "low obliques" when the optical axis is tilted no more than 30 degrees from the vertical, and "high obliques" that typically point around 60 degrees away from the vertical. In vertical photographs, the nadir (i.e. point on the ground directly below the camera at the time of exposure) is located approximately in their geometrical centre (principal point); while in the case of high obliques the position of the nadir is typically positioned outside the photo frame (Figure 1). Another significant difference is that verticals are often taken in so-called stereo pairs (subsequent frames have significant overlap of their ground coverage), enabling a "threedimensional" perception during visual analysis and offering advanced possibilities of precision mapping (Risbøl et al. 2015). Obliques are very rarely obtained in this way, their analytical potential thus being, technically speaking, more limited.

Verticals versus obliques can be compared based on practical considerations of data collection and processing, but not necessarily the most important one for a full appreciation of the actual potential of aerial photographs. No image taken by an optical sensor with a central projection of rays (all conventional cameras) captures the surface of the Earth truly vertically (orthogonally), thus making what we understand as a plan or map. This radial distortion of an image due to the vertical ruggedness of the terrain is explained in Figure 2. There is no simple transformation relationship between the central projection of any photo and the orthogonal map or plan. Correction of this type of distortion can be computed from a series of overlapping images, in which the apparent dislocation of points on the individual photographs can be explained by differences in their elevation. If stereo pairs of photographs are not available, a digital elevation model of the terrain can help to re-project a photo onto a horizontal plane (Hampton 1978).

Adjustments of the horizontal positions of captured data must therefore always be computed for both verticals and obliques. For this type of processing vertical photographs are much less problematic, because the perspective distortion as well as displacement due to elevation variances generally increase with the distance from the nadir. In vertical photos, these positional shifts as well as the distortions of shapes and lengths are smaller and more regularly distributed across the photo frame than is the case in high-angle obliques. However, it is clear that all photographs require a geometric correction before they are used for planimetry (measurements of distances, angles and areas). Therefore it might seem more suitable to link the difference between "oblique" and "vertical" imaging more generally with the strategy of data collecting (synthesising/interpretive vs. analytical), rather than with the type and orientation of the camera.

\section{Scale of photographs}

Archaeologists, and especially those insufficiently acquainted with vertical aerial photos, sometimes highlight the issue 


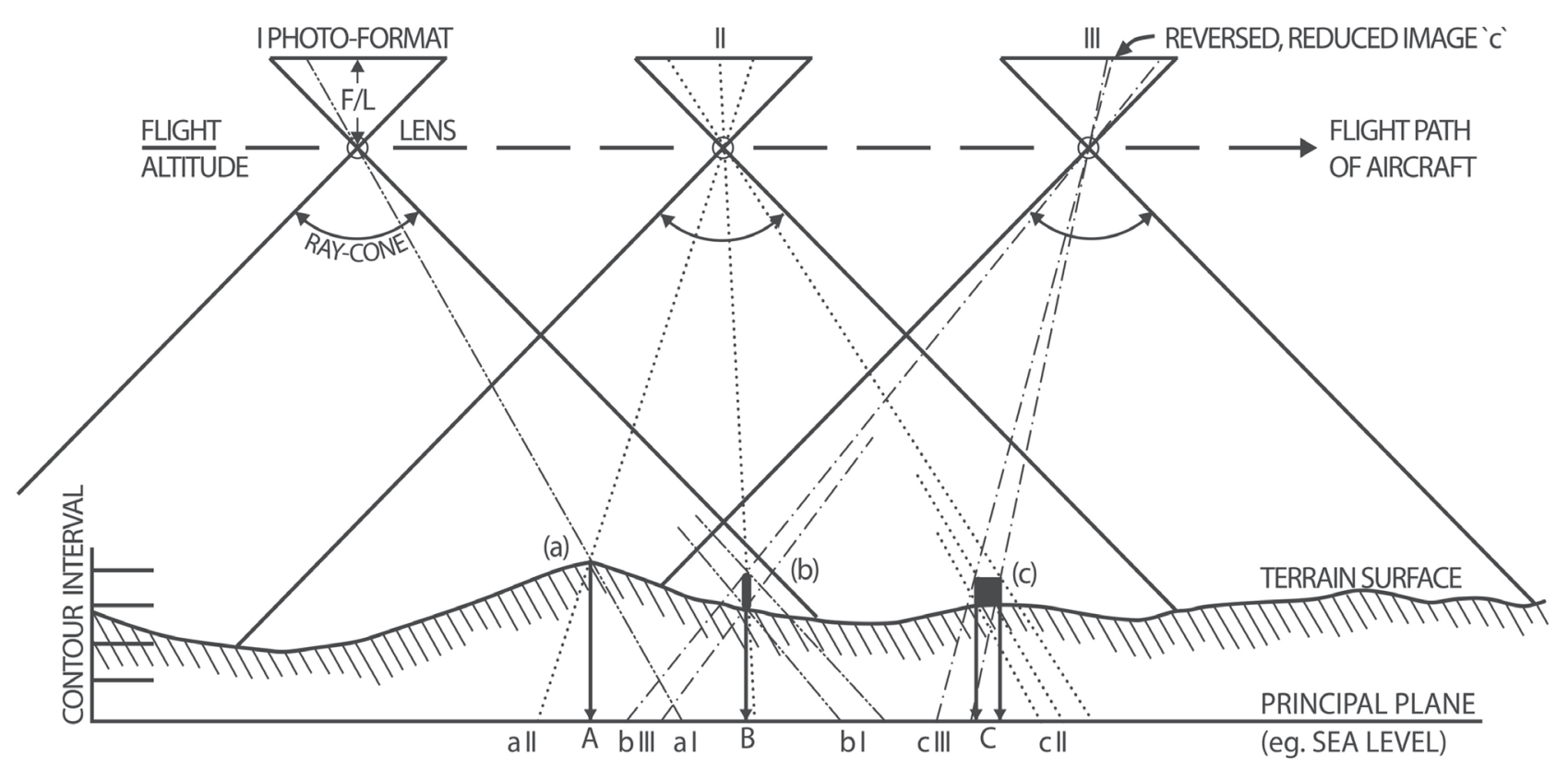

Figure 2. The concept of radial distortion of an image due to vertical ruggedness of the terrain on an aerial photograph. There is no simple transformation relationship between the central projection of the photo and the orthogonal map or plan. The correction of the distortion can be derived from a series of overlapping images, in which the apparent dislocation of points a, b, c on the individual photographs can be explained by differences in their elevation. Using the method of intersecting radial lines, their correct locations $\mathrm{A}$, B, $\mathrm{C}$ on the map can be derived (after Hampton 1978, Figure 17).

that the nominal scale of available vertical images is smaller than that required for fine-grained studies of archaeological heritage and that no details are visible. In many cases this is true of imagery taken for purposes other than archaeology, but in principle there should be no dramatic differences in this respect between vertical and oblique photographs, and this can be easily exemplified. To better understand this, we can consider imaging on film to illustrate the principle, even though film has largely been replaced by digital technology nowadays (Verhoeven 2007). We know that the nominal scale of an image on a film depends on the ratio between flight height (altitude above the terrain) and the focal length of the camera. When photographing the landscape using a common hand-held camera with a standard lens of focal length $\mathrm{f}=50 \mathrm{~mm}$ from an altitude of $500 \mathrm{~m}$, we get an image on the negative at a scale of 1:10,000 (500/0.05). For hand-held oblique photography, the use of a lens with a significantly longer focal length (a so-called telephoto lens) is mostly impractical in aerial prospection because such an arrangement can capture only small views and the image is too enlarged to be held steadily in the viewfinder because of constant vibrations and turbulence affecting the aircraft and its crew during the flight. In addition, the necessity to use a fast shutter speed in order to avoid blurred images calls for a wide aperture, which may in some cases decrease the sharpness of certain parts of the picture. Hence in oblique photography we can hardly obtain a significantly higher nominal scale than the value stated above.
Obtaining vertical images at approximately this same scale is not particularly a problem (for example, with the once common wide-angle aerial camera with $\mathrm{f}=152 \mathrm{~mm}$ from an altitude of $1,520 \mathrm{~m}$ above the ground). To give an example from central Europe, a limited number of verticals with this scale are available in the military archive of the Czech Republic in Dobruška (Břoušek, Laža 2006), although more frequently we can find photos there with a nominal scale ranging from 1:20,000 to 1:30,000. Nevertheless, large format negatives $(18 \times 18 \mathrm{~cm}$ or more recently $23 \times 23 \mathrm{~cm})$ can be enlarged without any significant loss of detail. Thus, we can conclude that in the end, we are working with enlarged oblique and vertical photographs of comparable scales (see also Doneus 1997; Palmer 2005, 103-104). Furthermore, the scale of oblique photographs dramatically decreases from the foreground to the background of the image, which, together with the distortion of shapes due to perspective, usually leaves parts of oblique photographs useless for detailed analysis.

Oblique photography using medium or large format film still has the advantage that we can get a greater enlargement of the details on the positive compared to vertical imaging from a greater height, but today most oblique photographs are probably taken on small format film or, increasingly, by a digital sensor, the resolution of which has only slowly been improved to approach the standard common in analogue photography. Past studies have concluded that the necessary density of data was not present in the primary digital record 
due to obvious technical limits and that digital imaging could not at that time surpass traditional film (Owen 2006; Verhoeven 2007). However, the emphasis on a completely digital workflow is strong, and there are also further benefits stemming from the use of digital technology for data collection, which will likely dictate future trends (Heipke et al. 2006).

Small, mass-produced cameras and their lenses are usually designed for entirely different purposes and are subject to other standards than those used in professional aerial cameras; this has an impact on the quality of the data collected together with differences in the types of media used for data storage (Scollar et al. 1990, 78-121). However, archaeologists may tolerate greater imprecision in the ground location of the objects of their interest (up to several metres or more, depending on circumstances) in contrast to some highly specialised geodetic applications. So the distortion caused by using non-calibrated cheap cameras is usually not considered fatal.

\section{Interpretive vs. analytical approach to aerial reconnaissance}

Oblique photography is essentially a very selective type of data collection, and thus it represents a synthesizing approach to archaeological survey. It is usually undertaken from a small plane with the aim to photographically record, in the best way possible, the features that attract the attention of the observer and seems significant for an archaeological understanding of the targeted area at the time of flyover (Figure 3).

This means that during the flight a synthesis of empirical observation is taking place, leading to the decision of whether or not permanent documentation should be made. The whole process is rather quick, executed simultaneously with ongoing navigation and communication with the pilot, and often in somewhat stressful conditions caused by air turbulence, sharp sunlight or nearby air traffic. Undoubtedly, this work environment is not ideal for any kind of in-depth analysis and researchers working in this field generally agree

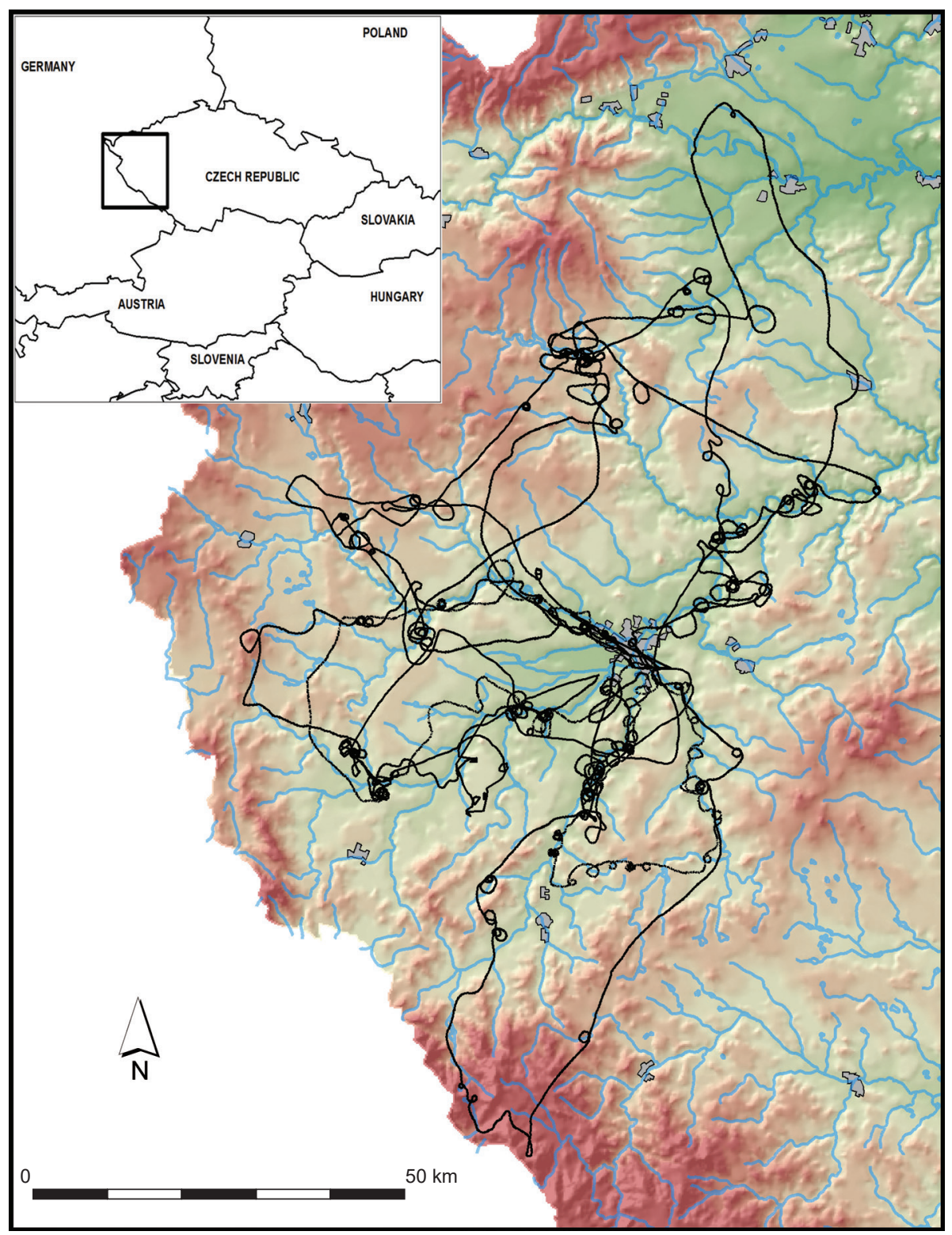

Figure 3. GPS record of "synthesizing survey" flights conducted by the author in 2006 in the region of West Bohemia. 
that only the most distinctive features are usually recorded where their presence is expected beforehand and the attention of the researcher is focused on this specific task. Apart from these, there may be many other remains of past human activities in the studied region, overlooked or neglected for a number of reasons that escape recording even after relatively intensive survey periods (Gojda 2003, 71-72).

This potential weakness of a synthesising strategy to aerial survey is well documented by the following example: In Scotland, where aerial prospecting has been used since the 1940s, the elongated prehistoric enclosures of the cursus type remained virtually unknown until the 1970s, probably because their presence was not expected there and attention had been paid mostly to the remains dating from the Roman period. During the last forty years, their number has increased to several dozens thanks to prospecting redirected toward their identification and partially due to the reinterpretation of previously-taken images. A new analysis of these older photos has shown that they had already captured these features, but their original interpretation was incorrect (Brophy, Cowley 2005).

Vertical imaging represents a very different method one which can be labelled as an "analytical approach" to data collecting. In this case, photographing a selected area is undertaken systematically (sticking to chosen technical parameters, such as the flight height and flight path, focal length of camera, number of photographs necessary to cover the extent of studied landscape transect, etc.) and represents a spatially continuous record of the landscape under comparable conditions (light, state of vegetation, etc.) over the whole surveyed area (Figure 3). The specialist analysis, synthesis of information and its interpretation take place after the flight has ended. It is then possible to apply various approaches to the evaluation of the captured images, their analysis can be done independently by more people, it is plausible to apply a range of technical tools that complement or enhance the human senses, and so forth. In this way we can repeatedly look at large portions of the landscape in detail and in conditions which are more favourable to the identification of even relatively unpronounced and previously unexpected features. Photographs taken by vertically-oriented aerial reconnaissance cameras also represent a technically standardised visual record of the Earth's surface (Figure 4), which requires less geometric transformation for precise mapping compared to oblique images. Here we touch on the field of photogrammetry, the science of accurate measurements of real-world objects by means of their photographic representation. Advanced methodologies of photo orthorectification have been developed and are improving further (Schenk 2004); the necessary procedures and tools are today incorporated in a number of available computer programs (Heipke 1996; Pavelka 1999; Lillesand et al. 2015).

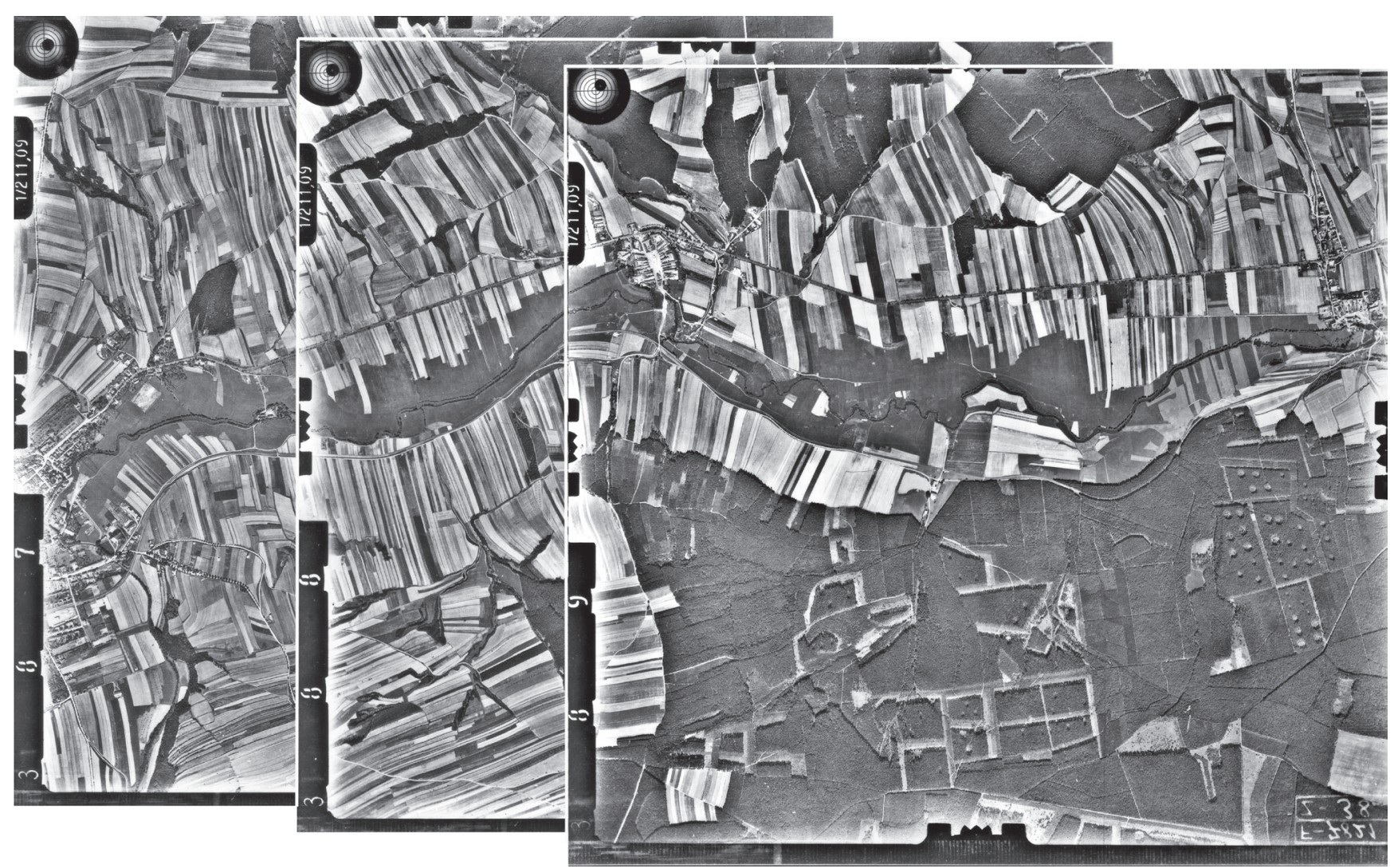

Figure 4. An example of three overlapping vertical aerial photographs from a single sortie, providing a systematic record of the landscape. Source: Military Geographical and Hydrometeorological Institute in Dobruška, adapted by the author. 


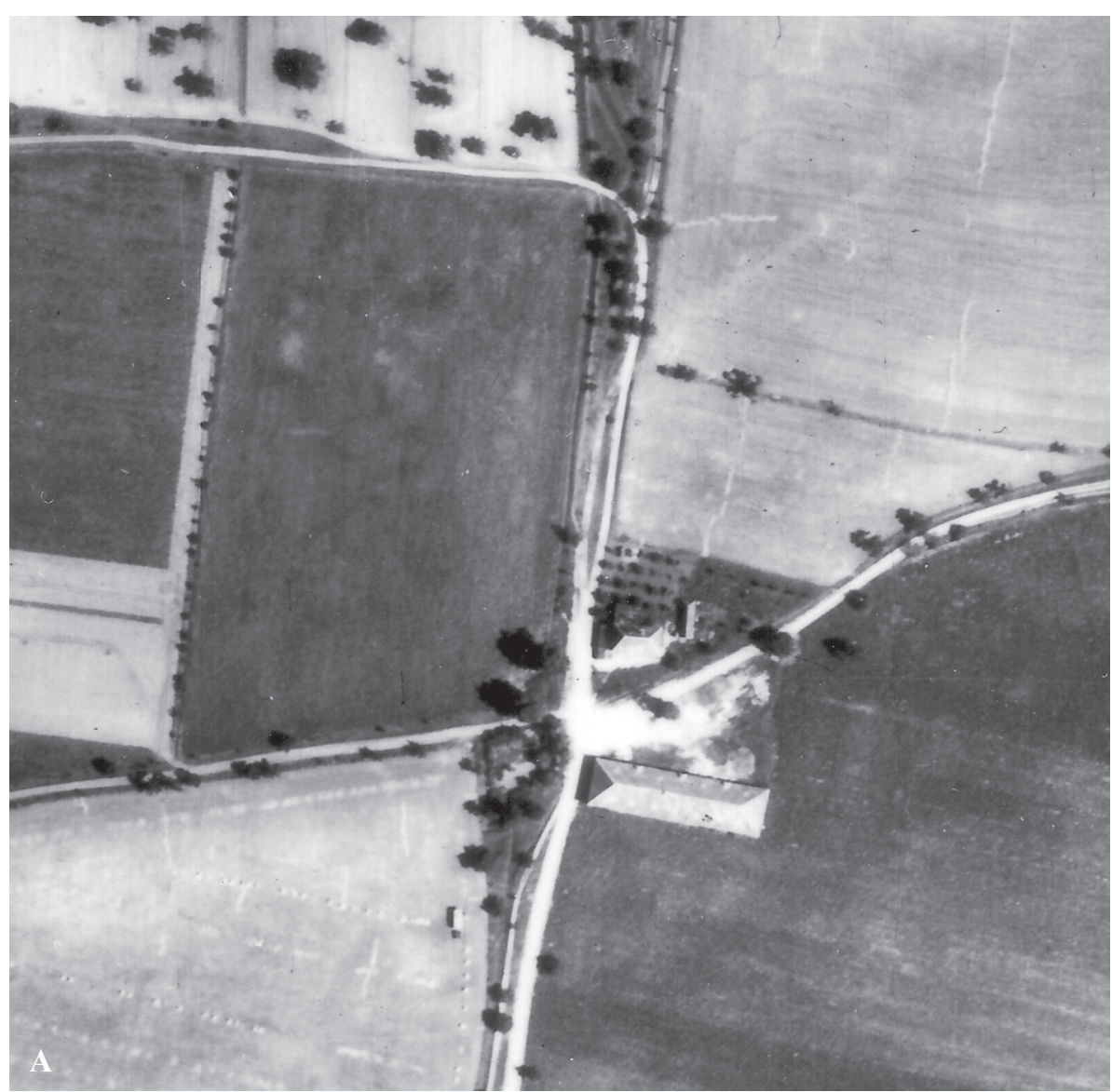

Figure 5. Mnetěš, Litoměřice District,

Czech Republic. Gradual dilapidation of a former sheep house, as recorded on vertical aerial photographs in 1946 (A), 1973 (B) and 2007 (C). A pronounced linear cropmark on the youngest picture reveals the position of a ditch dividing fields on both earlier images. Source: Military Geographical and Hydrometeorological Institute in Dobruška $(\mathrm{A}, \mathrm{B})$ and Geodis Brno $(\mathrm{C})$.

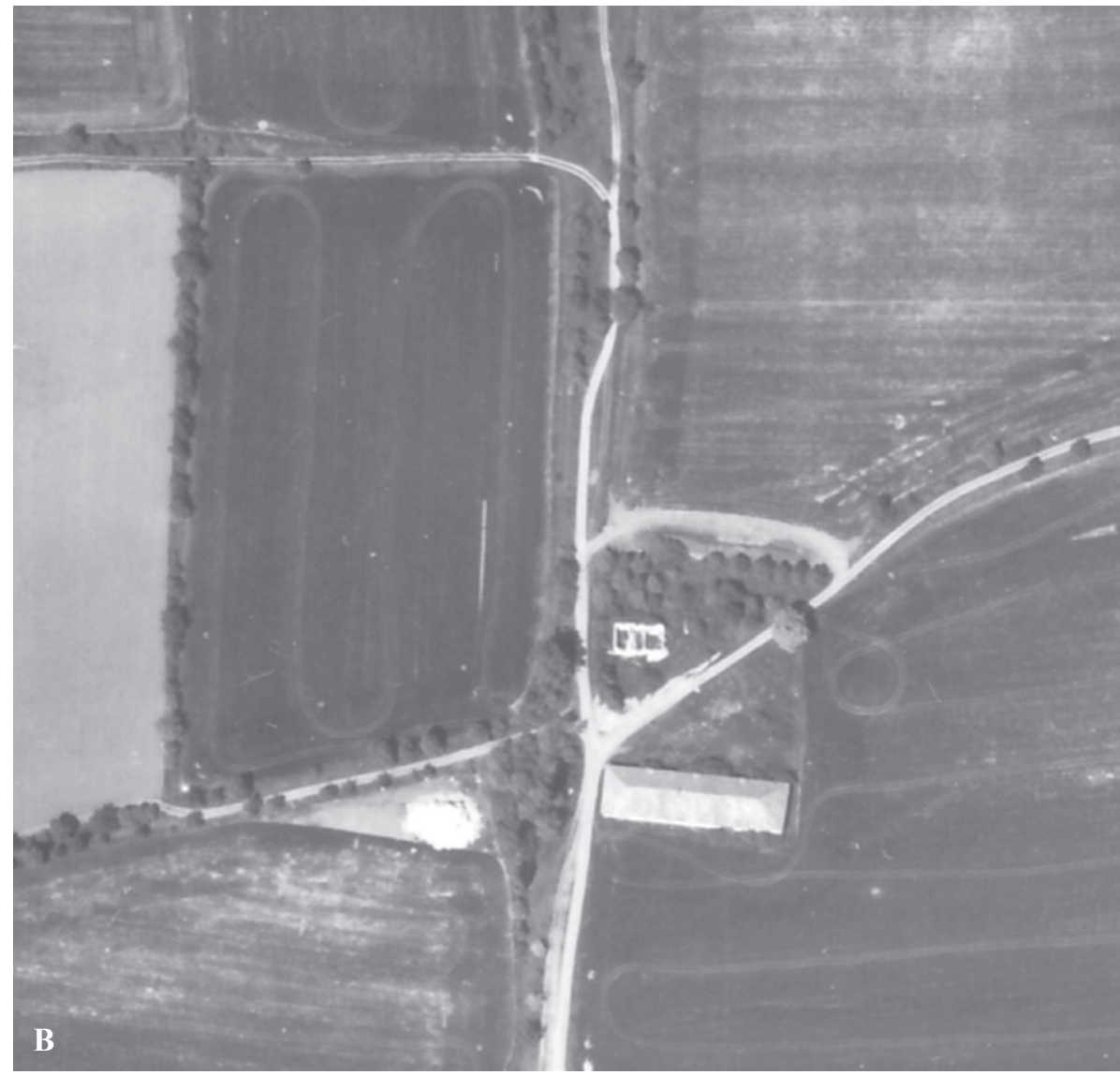


Figure 5. Mnetěš, Litoměřice District, Czech Republic. Gradual dilapidation of a former sheep house, as recorded on vertical aerial photographs in 1946 (A), 1973 (B) and 2007 (C). A pronounced linear cropmark on the youngest picture reveals the position of a ditch dividing fields on both earlier images. Source: Military Geographical and Hydrometeorological Institute in Dobruška (A, B) and Geodis Brno (C). (Continuation)
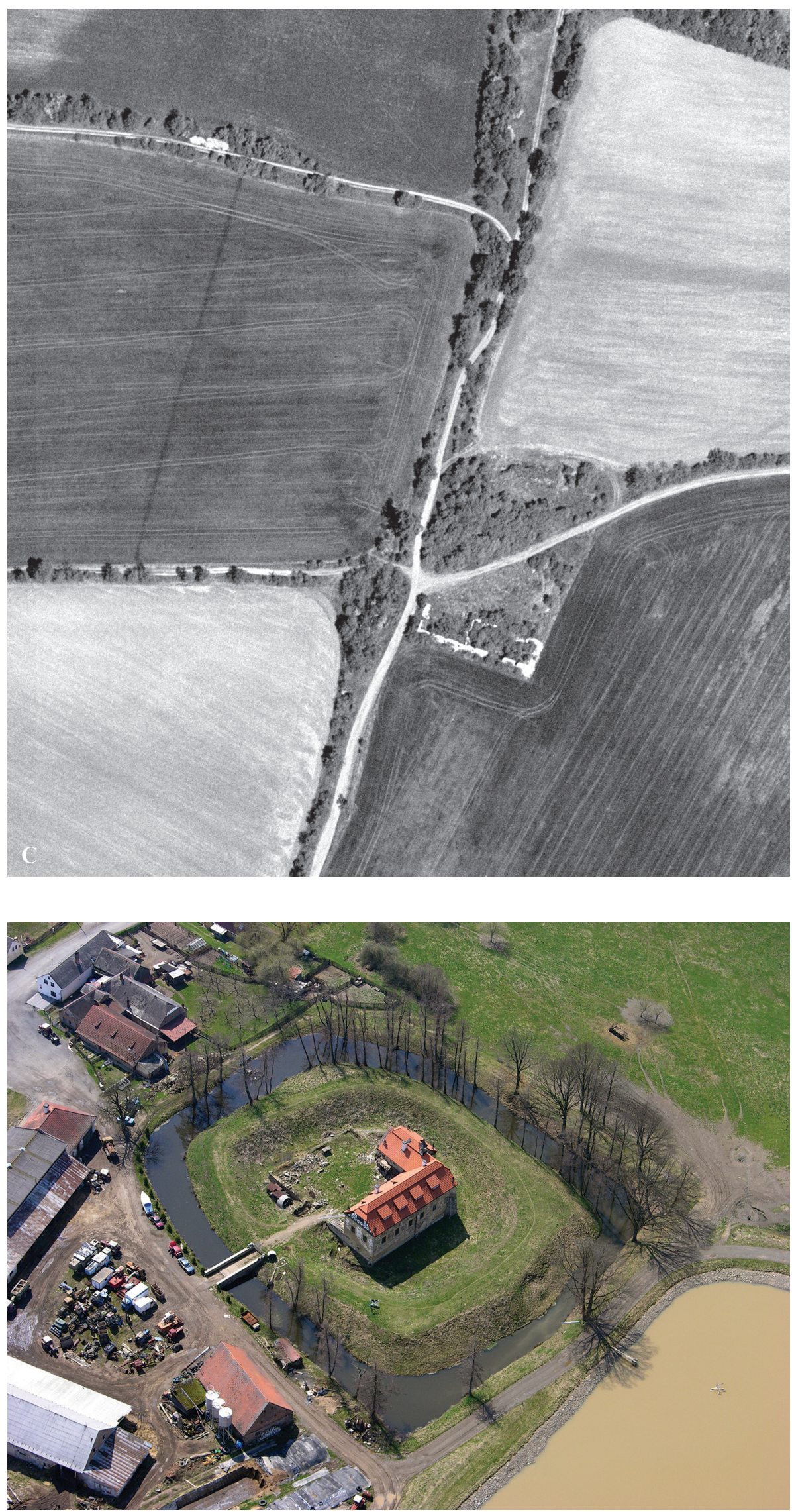

Figure 6. Vlkošov, north of Plzeň, Czech Republic. The recent appearance of a late mediaeval keep surrounded by a water-filled moat (photo by the author from $24^{\text {th }}$ April 2006). 
It is undeniable that working with vertical images requires longer practical experience, tools for image enlargement and, if possible, also technical equipment for stereoscopic perception. When these requirements are met, practically all vertical images can offer valuable information for research into historic landscapes, even though they may not necessarily be represented by the spectacular cropmarks that the public (as well as many professionals) primarily link with aerial archaeology. A great many features of cultural heritage are preserved in the landscape. Most of these remain unnoticed or unrecorded due to several factors: researchers follow other objectives set by their work agenda, or the current theoretical paradigms of the relevant disciplines do not favour particular types of sites, or researchers preferably target other (better-preserved and more visually-striking) study sites, and, last but not least, there is a lack of knowledge about the technical possibilities of studying these features.

Comparing the two categories of aerial photographs from just one other perspective, we cannot assume that the relatively few practitioners involved in oblique aerial photographing in archaeology could record a truly representative sample of all the possible classes of remains and features of historic landscapes. Luckily there are archives of vertical images in which the topography of the entire country is unselectively recorded and by which its appearance and condition has been periodically monitored. Of course, some problems are encountered in forested areas that are difficult to handle by conventional photography. In this type of environment, airborne laser scanning (ALS/LIDAR) today provides invaluable help to an ever-increasing level, because laser pulses are, to a certain degree, able to penetrate the vegetation canopy (Doneus et al. 2008; Gojda, John 2013; Trier et al. 2015). Despite these technological advances, aerial photographs still remain an important source of information, as their potential has so far only been evaluated to a minor level. An extensive amount of yet unexamined data persists in archives, as can be illustrated by the examples of deserted field systems, mining areas, sheep houses, churches, roads, tracks, etc. (Figure 5 gives an example illustrating this point).

Another important advantage with vertical images is that in permanently inhabited areas they always include enough control points for precision mapping. Thus we can avoid the issue that is quite typical for oblique images, in which the effort to capture the archaeological features in detail often (paradoxically) makes their precise metric analysis impossible because of the lack of reliable ground control points (Gojda 2004b, 100; Palmer 2005). Even in cases when oblique aerial photos capture targeted sites in their wider landscape context (which is not always the case), they unavoidably suffer from great perspective distortion of the ground representation that, combined with other types of problems, complicates their geometrically correct transcription onto a plan or map (e.g. terrain height variation, optical distortions of common cameras). Hence mapping conducted on the basis of oblique photographs meets significant difficulties, especially in regions with larger areas of fields (and lower density of ground control points), a situation quite common in many countries with intensive agriculture.

Oblique imaging undoubtedly has its own advantages as it offers great flexibility in the choice of timing and viewing angles, as well as many options of working with light to capture a visually impressive picture. It also allows for experimenting with various photographic techniques, media for data storage, etc. Images obtained in this way usually well illustrate the general appearance of historic sites to the wider public (Figure 6) because they do not need to be magnified and they are taken from a perspective close to everyday human experience (Grady 2000, 25-26). Individual images of this kind represent a detailed view of concentrated archaeological information. This can be both an advantage and disadvantage depending on the situation. The clear and detailed definition of features is certainly a positive aspect of oblique photography, but the absence of a wider landscape context (which would facilitate interpretation and mapping by referencing the local topography) may be seen as its major disadvantage. By contrast, the landscape setting of any place of interest is naturally available for study in every systematic vertical imaging (Doneus 2000, 36).

To sum up this section, the use of oblique images in accurate mapping remains rather difficult and the technical problems rapidly worsen with increasing deviation of the image's principal axis from vertical. The optical parameters of the cameras used are usually not known with sufficient precision and quite often rigorous photogrammetric approaches cannot be applied. Despite these problems, methods of their (approximate) rectification are still available and in many cases they can be considered sufficient. Apart from the option to georeference raster images in present-day geographic information systems (e.g. ESRI ArcGIS), there are computer programs created specifically for aerial archaeology, the best known of which are probably Aerial and AirPhoto (Haigh 1995; Scollar 1998). These are relatively cheap and easy to use, and even have the option to take into account the terrain height to achieve higher precision, but they necessarily lack the versatility and extensive user support compared to the more generally-oriented commercial products aimed at larger markets.

A significant and virtually unavoidable problem with many oblique images is the aforementioned absence of a sufficient number of suitable ground control points, which would allow accurate transcription of the image into a map. In principle, the use of stereoscopic analysis is possible for oblique images and would undoubtedly aid their interpretation and transcription, but photographs are usually not taken for this purpose and do not meet 
the requirements for facilitating a three-dimensional perception.

Other aspects that we need to consider, along with the basic technical parameters of the images, are the temporal and financial constraints. Outsourced vertical imagery, delivered by a national agency or commercial company can in many ways save researchers' time, allowing them to dedicate their resources to specialised tasks linked directly to their archaeological or cultural heritage agenda. Prospecting with oblique imaging if it is to be done effectively requires a virtually constant readiness to make use of suitable meteorological and light conditions and exchange costly flight time for documentation of the highest possible quality. For a systematic project in a chosen region, many flight hours during the year are necessary, to which we must add not only the significant time spent for every flight preparation but also the subsequent recording of individual flight routes and the observations made, archiving of photographs, etc. It is estimated that each hour spent in the air requires four hours (or up to eight hours, depending on circumstances) after landing dedicated to these post-flight activities (Musson 1995, 63). The specialist analysis of the images and work with the data collected can only commence afterwards.

\section{Timeliness of aerial survey}

One of the common complaints one can hear in the archaeological community about vertical photographs is that most of them were commissioned for non-archaeological purposes (e.g. for cartography or civil engineering) and therefore are lacking properties that are optimal for archaeological prospection. This raises the question of how we can generally determine which season of the year is best for archaeological reconnaissance. There is no doubt that a heavy preference for one particular set of conditions, typically those producing well-developed cropmarks (Riley 1979), is certainly productive in its one-sidedness (Gojda 2004b, 76), but at the same time, such an empirical bias causes many other indicators of anthropogenic landscape features to be neglected. Valuable information can certainly be captured in any season of the year. This is not to deny that having more historical photos taken in the main season for cropmarks would be helpful (for central Europe, this period is from May to July). We simply have to accept the fact that these are rarely available in the existing archives because the peak of the vegetative cycle is not an ideal time for the collection of cartographic data. Fully grown vegetation covers the terrain, causing difficulties for the extraction of elevation models using the photogrammetric method (Fabris, Pesci 2005).

Until the second half of the twentieth century, the campaigns of aerial photo reconnaissance in the Czech Republic were often undertaken when most fields had been harvested (i.e. from high summer to the beginning of autumn). Precise dates, apart from the year, were usually not recorded or have not survived for the first decades of systematic military reconnaissance in the Czech Republic (this material is held in the archive of

Figure 7. Harvested fields on an enlargement of a vertical aerial photograph from 1946. Source: Military Geographical and Hydrometeorological Institute in Dobruška.

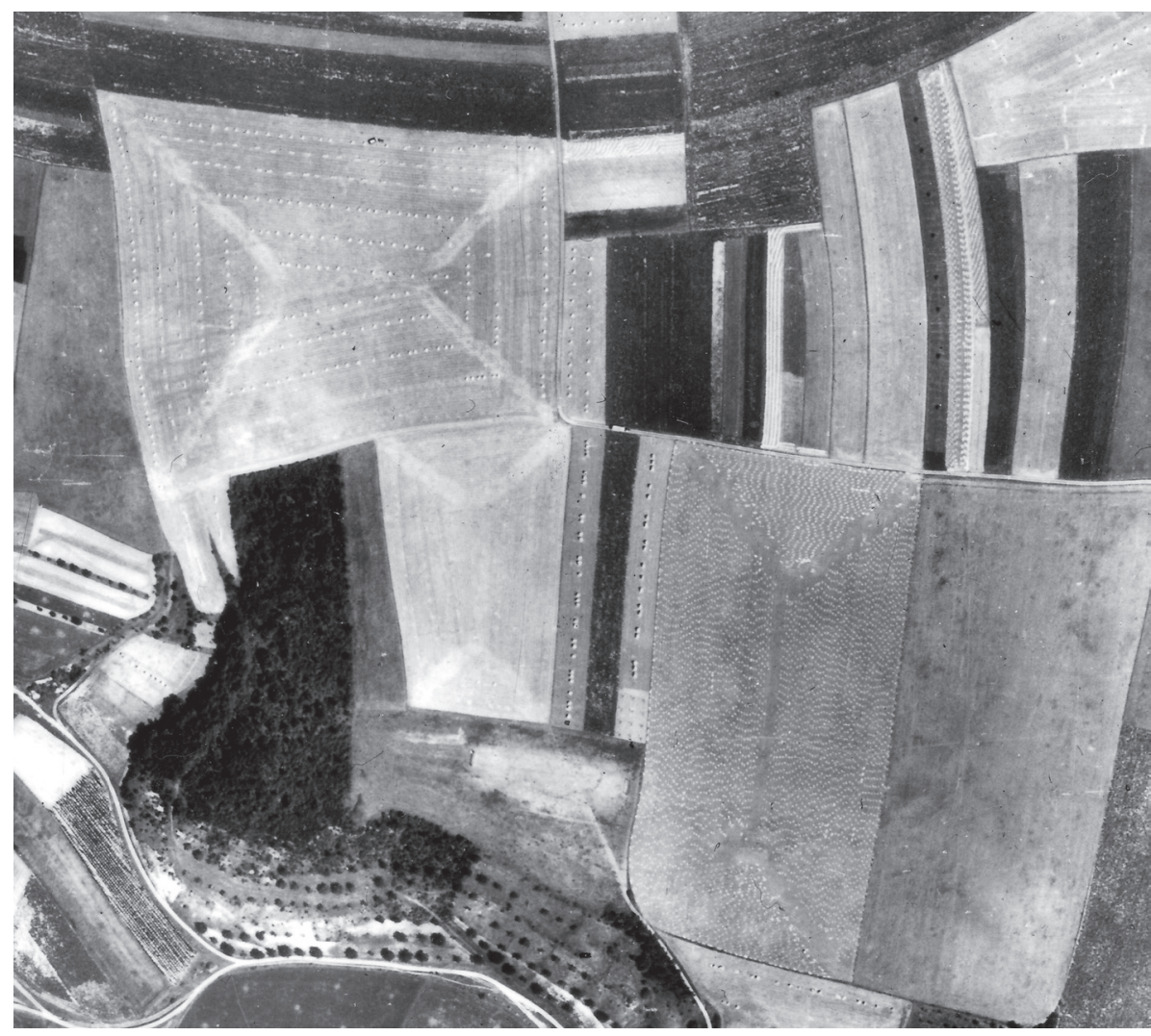


the Military Geographical and Hydrometeorological Institute in Dobruška), but the season is indicated by the numerous sheaves on the fields and by the typical "envelope-like" pattern on larger stubble fields, caused by harvesting the outer strip around the edges of a field first, followed by another strip nearer to the centre and so on (Figure 7). This means that a considerable portion of the fields is free of standing crops in these photographs and the anticipated marks showing the presence of subsurface archaeology can be identified only by chance on fields that had not yet been harvested, or rather rarely on stubble fields and grassland.

The national programmes of aerial photographic campaigns for cartographic purposes in the Czech Republic have in recent decades been undertaken in April and May, which seems to be a bit too early for the purposes of archaeological prospecting. However, when the spring weather is favourable, we can get a very good record of the early phase of cropmarks, either on winter cereals (Figure 8) or on other early crops such as rape (Brassica napus). In addition, when concurrent favourable factors generate good conditions for the early development of cropmarks, we can observe very fine details thanks to the low height of plants, which later partially disappear when the vegetation grows taller and overweight stems tend to bend over.

Apart from the fact that we usually lack vertical images taken at the height of summer, we also do not have enough documentation from the winter season that make use of snow marks (Becker 1996a, Abb. 1; 1996b,
Farbtafeln XXXV-XXXVII; Braasch 1996; Faßbinder, Irlinger 1996, Farbtafeln XXXI-XXXII; Fröhlich 1997, Abb. 7, 90, 91; Leidorf 1996, 42; Stanjek, Faßbinder 1996); such coverage is very rarely represented in many existing archives. Some hope in this respect is offered by the surviving photographs taken in air reconnaissance during the Second World War and during the subsequent, so-called Cold War period (Cowley, Stichelbaut 2012; Going 2002; 2006; Rączkowski 2004), where these seasons might be better represented, even though the geographical coverage and actual number of surviving photographs will be limited.

Another temporal layer for comparison of vertical and oblique imaging is the time of day when the photographs of a given area are taken. Here we also encounter a conflict between the needs of archaeology and cartography. Oblique archaeological imaging gains most information from photographs taken in the morning and in the evening, when the low angle of sunlight accentuates anthropogenic modifications in the terrain (Figure 9) or even cropmarks by casting shadows (Crawford, Keiller 1928; Gojda 2004b, 82). On the other hand, vertical images commissioned primarily for the purpose of making topographic maps are taken at the time of day when shadows are minimal because they diminish the "legibility" of the Earth's surface and hinder taking precise measurements in the affected areas (Burnside 1979, 33). That is the reason why the terrain often looks very flat and seemingly monotonous on individual vertical photographs, but once we interpret

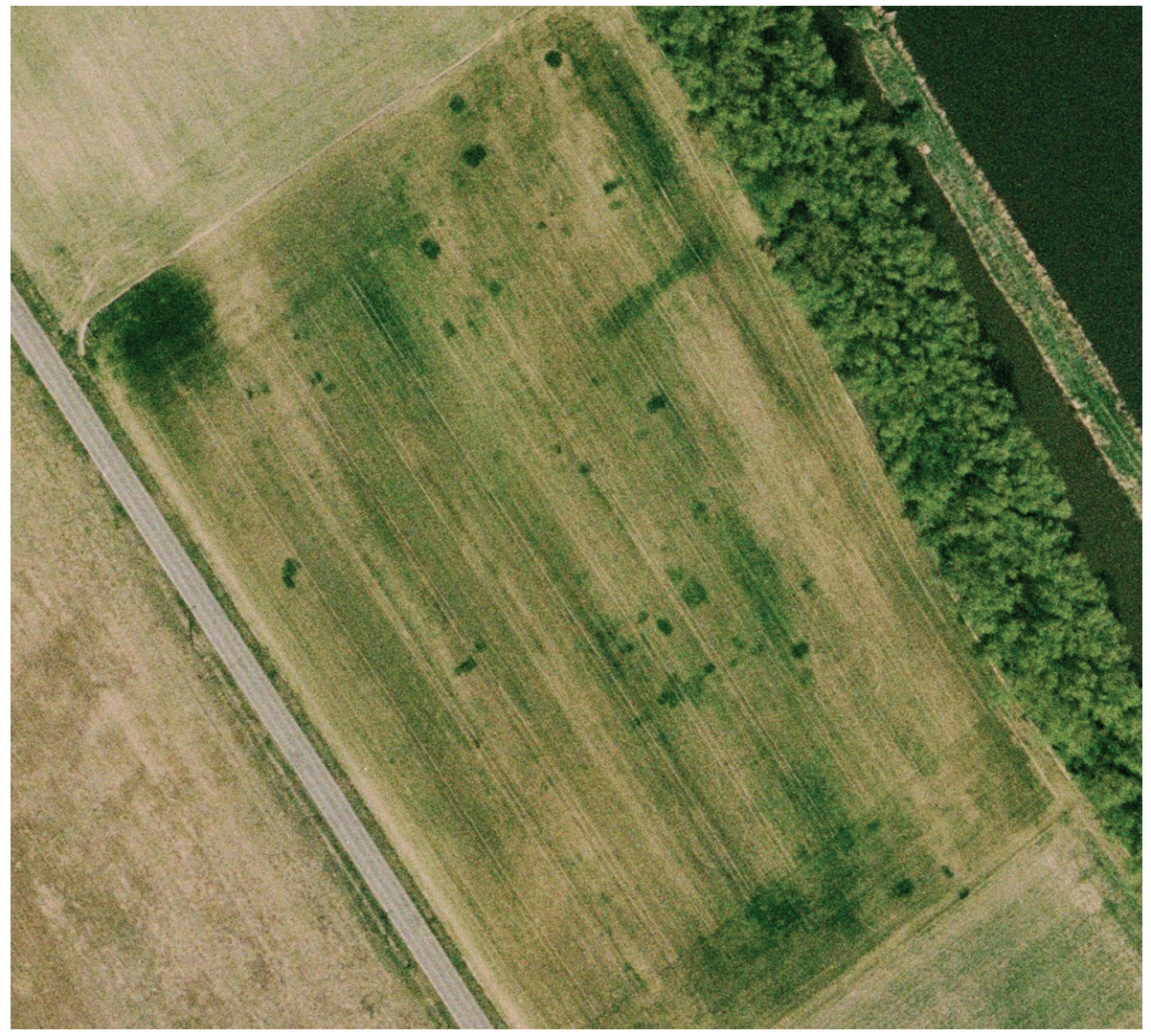

Figure 8. Horní Počaply, Mělník District, Czech Republic. Maculae visible on a field with a winter crop. An enlargement of a vertical photograph taken primarily for cartographic purposes on $28^{\text {th }}$ April 2007. Source: Geodis Brno. 


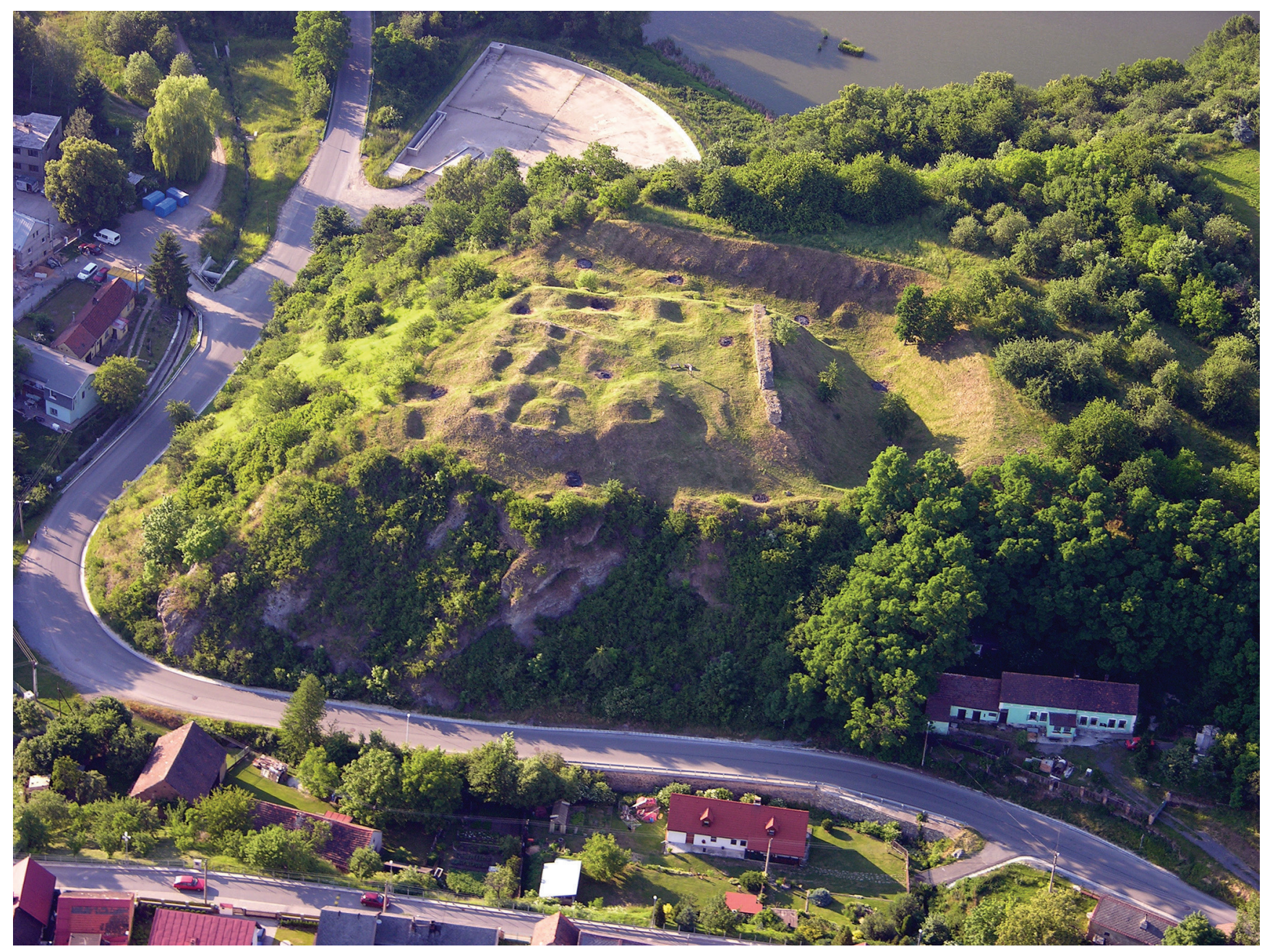

Figure 9. Litice, Plzeň-město District. An oblique image captures a comprehensive view of the castle remains, highlighted by shadow marks, but it is not suitable for their precise mapping (photo by the author from $20^{\text {th }}$ June 2005).

stereo-pairs of images allowing three-dimensional perception this problem almost disappears (Avery, Lyons 1981; Bradford 1957).

\section{Impact of new technology}

Current technological advances make some aspects of aerial prospection significantly easier. These include digital photography, GPS, GIS and Internet, which can all be interconnected during the survey itself and the subsequent processing of collected data (Doneus 2006; Leckebusch 2005; Nagy, Schlenther 2007). On the other hand, it should be highlighted that the direction in which the development is heading clearly leads away from the key role of individual surveyors, whose personal dedication, skills and effort gave birth to aerial archaeology and nurtured it from the very beginning, to the coordinated cooperation between specialists from a range of disciplines. Without such cooperation the potential of the current technologies cannot be fully reached. It logically follows that with this trend the financial cost of survey undertaken by archaeologists is growing (and will be growing), and so are the demands on their familiarity with the technologies used and on securing the long-term storage and maintenance of the fast-growing volume of typologically varied data (Bewley et al. 1999; Doneus 2006).

Currently, we do witness an enormous increase in the number of available types of UAVs (unmanned aerial vehicles, or drones) in the civil sector. These devices will dramatically reduce the costs of analytically undertaken archaeological prospecting, especially in smaller study areas, and they are capable of removing one of the few truly apparent advantages of oblique imaging from small aircraft: the high flexibility of the timing and recording methods (Colomina, Molina 2014; Lambers et al. 2007). Considering this technological development, UAVs may effectively close the gap between the two formerly competitive strategies: the analytic approach of vertical photogrammetric imaging, and the synthesising survey strategy intrinsically connected with oblique imaging. We are entering an era when we can utilise the complete range of approaches from the purely analytic to the precisely targeted interpretive prospecting, and take into account specific research questions, environmental and 
technical constraints, as well as the limited budgets of archaeological projects.

\section{Conclusion}

In contrast with surveys based on the practice of an interpretive approach and oblique photography, analytical aerial prospecting makes use of vertical photography where the technical issues, including the necessary procedures during flight and the primary archiving of images, are taken care of by the specialised personnel of a particular professional institution (so far it is unlikely that this type of imaging could be effectively undertaken by archaeologists themselves). The archaeologist can thus invest the financial resources into purchasing the ready-to-use data providing a complete and standardised analytical coverage of the study area instead of buying flight time for one's own aerial reconnaissance. The researcher's time can then be dedicated to the study and interpretation of the delivered imagery-that is, directly to specialised archaeological work.

While systematic analytical surveys are highly advantageous for archaeology in many aspects, there remain some problems which justify oblique photography to be undertaken in parallel. Factors in favour of synthetic aerial survey include the relative freedom to mix various aspects that play a key role when certain knowledge enhancement requires very specific details to be captured in pin-pointed areas - details that need the carefully targeted effort of a skilled specialist in historic landscape studies. Oblique imaging has often contributed to a successful interpretation with details not visible on vertical images. Hence the approaches can be considered complementary in many respects and the

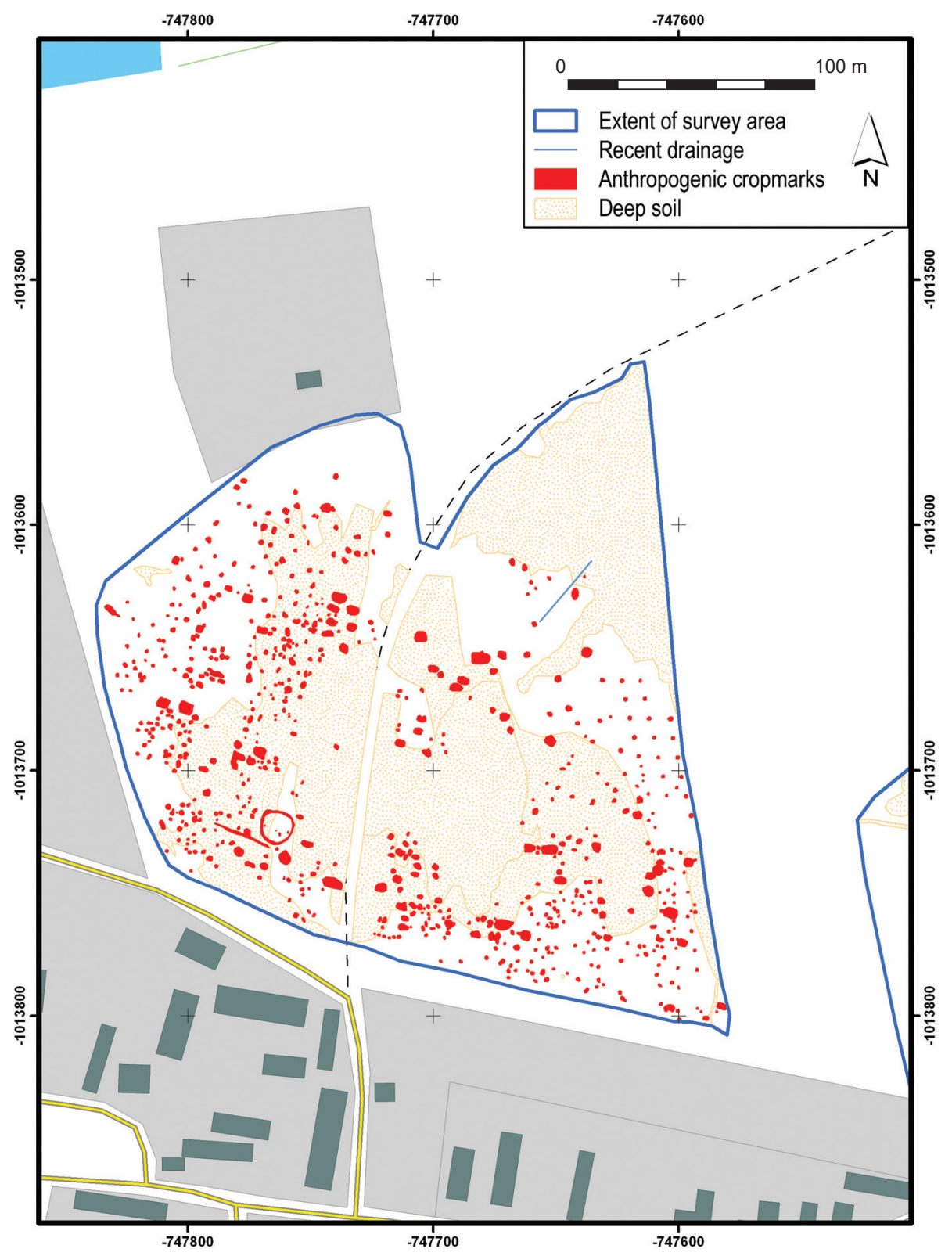

Figure 10. Ledčice, Mělník District. An archaeological interpretation of a compilation of vertical and oblique aerial photographs transcribed into a map in GIS 
Table 1. A comparison of selected characteristics of vertical and oblique aerial photos (i.e. analytical and synthetic survey) in the Czech Republic.

\begin{tabular}{lcc}
\hline \multicolumn{1}{c}{ Parameter } & Vertical imaging & Oblique imaging \\
\hline Strategy of research & + analytic & - synthetic \\
Intensity of data collecting & + high & - low \\
Landscape context & + yes & - no \\
Enough control points & + yes & - often no \\
Possibility of 3D analysis & + yes & - no \\
DMT calculation & + yes & - no \\
Orthorectification & + yes & - problematic \\
Archives of historical images & + yes & - no \\
Interpretation requirements & - high & + low \\
Flexibility & - low & + high \\
\hline
\end{tabular}

most productive projects will probably be those that will manage to get the most from combining both strategies (Doneus 2000, 36-38). One example of results obtained by this combined strategy is shown in Figure 10.

The redundancy of data produced using both methods is also useful as it brings the possibility to control the spatial delimitation and interpretation of features of uncertain origin and/or function. Independent observation (imaging) and the mutual evaluation of various interpretative alternatives is often critical for finding a satisfactory understanding of enigmatic discoveries, which can be subsequently tested by geophysical survey, field-walking, test excavation and the like. By combining both survey strategies we can successfully bridge the known differences between their capabilities, which are often apparent in the practice of both surface survey (field-walking) and aerial prospecting. The analytical approach usually brings a quantitatively and spatially well-balanced distribution of data, but compared to the synthesizing approach it lags behind in quality and richness of detail that can only be present when our attention is focused at an optimal time on one spot where this detail is momentarily accessible. An attempt to summarize the pros and cons of both strategies of data collection is shown in Table 1.

\section{Acknowledgements}

This paper is dedicated to Martin Kuna, a distinguished scholar and great friend. Throughout his career he has contributed his bright insights to many important topics, and he continues to inspire researchers and students in his own country as well as abroad. Many years ago, the author had the opportunity to fall under his pedagogical influence and the good luck to become his friend and colleague. One of Martin's research themes is analytical surface survey and its integration into the system of archaeological prospecting.

This work was supported by the project CIGA 20144207 (Czech University of Life Sciences Prague).
I wish to thank two anonymous reviewers who commented on an earlier draft of this paper.

\section{References}

AVERY, T. E., LYONS, T. R. 1981: Remote Sensing: Aerial and Terrestrial Photography for Archeologists. Cultural Resources Management Division, National Park Service, U.S. Department of the Interior, Washington.

BECKER, H. 1996a: Die ersten Häuser in Bayern vor 8000 Jahren: Jungsteinzeitliche Langhäuser bei Regensburg-Harting. In: Becker, H. (Ed.): Archäologische Prospektion. Luftbildarchäologie und Geophysik. München, 82-96.

BECKER, H. 1996b: Ein keltischer Tempel als Bewuchsmerkmal im Getreide - Die Viereckschanze bei Hartkirchen. In: Becker, H. (Ed.): Archäologische Prospektion. Luftbildarchäologie und Geophysik. München, 191-197.

BEWLEY, R. H., DONAGHUE, D., GAFFNEY, V., VAN LEUSEN, M., WISE, A. 1999: Archiving Aerial Photography and Remote Sensing Data. Archaeology Data Service, York.

BRAASCH, O. 1996: Luftbildarchäologie, ein Wintermärchen? In: Becker, H. (Ed.), Archäologische Prospektion. Luftbildarchäologie und Geophysik. München, 55-68.

BRADFORD, J. 1957: Ancient Landscapes: Studies in Field Archaeology. Bell, London.

BROPHY, K., COWLEY, D. 2005: From the air: An introduction. In: Brophy, K., Cowley, D. (Eds.): From the Air: Understanding Aerial Archaeology. Tempus, Stroud, 11-23.

BŘOUŠEK, L., LAŽA, L. 2006: 55 let vojenské geografie v Dobrušce. Vojenský geografický obzor 1, Př́loha 1, Dobruška.

BURNSIDE, C. D. 1979: Mapping from Aerial Photographs. Granada Publishing, London.

COLOMINA, I., MOLINA, P. 2014: Unmanned aerial systems for photogrammetry and remote sensing: A review. ISPRS Journal of Photogrammetry and Remote Sensing 92, 79-97.

COWLEY, D. C., STICHELBAUT, B. B. 2012: Historic aerial photographic archives for European archaeology. European Journal of Archaeology 15, 217-236.

CRAWFORD, O. G. S., KEILLER, A. 1928: Wessex from the Air. Clarendon Press, Oxford.

DONEUS, M. 1997: On the Archaeological Use of Vertical Photographs. AARGnews. The Newsletter of the Aerial Archaeology Research Group $15,23-27$.

DONEUS, M. 2000: Vertical and oblique photographs. AARGnews. The Newsletter of the Aerial Archaeology Research Group 20, 33-39.

DONEUS, M. 2006: Using GPS with digital cameras. AARGnews. The Newsletter of the Aerial Archaeology Research Group 33, 28-33. 
DONEUS, M., BRIESE, C., FERA, M., JANNER, M. 2008: Archaeological prospection of forested areas using full-waveform airborne laser scanning. Journal of Archaeological Science 35, 882-893.

FABRIS, M., PESCI, A. 2005: Automated DEM extraction in digital aerial photogrammetry: precisions and validation for mass movement monitoring. Annals of Geophysics 48/6, 973-988.

FAßBINDER, J., IRLINGER, W. 1996: Blick mit der Magnetik in die Grabkammern vorgeschichtlicher Grabhügel. In: Becker, H. (Ed.): Archäologische Prospektion. Luftbildarchäologie und Geophysik. München, 169-175.

FRÖHLICH, S. 1997: Luftbildarchäologie in Sachsen-Anhalt. Landesamt für archäologische Denkmalpflege Sachsen-Anhalt - Landesmuseum für Vorgeschichte, Halle (Saale).

GOING, C. J. 2002: A neglected asset. German aerial photography of the Second World War period. In: Bewley, R. H., Rączkowski, W. (Eds.): Aerial Archaeology: Developing Future Practice. IOS Press, Amsterdam, 23-30.

GOING, C. J. 2006. Signposts for GX; Looking for prints. AARGnews. The Newsletter of the Aerial Archaeology Research Group 32, 30-31.

GOJDA, M. 2003: Letecký průzkum a identifikace komponent sídelních areálů prostřednictvím porostových př́znaků: metodické poznámky. In: Šmejda, L., Vařeka, P. (Eds.): Sedmdesát neustupných let. Sborník $k$ životnimu jubileu prof. Evžena Neustupného. Katedra archeologie FF ZČU, Plzeň, 65-73.

GOJDA, M. 2004a: Ancient Landscape, Settlement Dynamics and NonDestructive Archaeology. Czech research project 1997-2002. Academia, Praha.

GOJDA, M. 2004b: Letecká archeologie a dálkový průzkum. In: Kuna, M. (Ed.): Nedestruktivni archeologie: teorie, metody a cile-Non-destructive archaeology: theory, methods and goals. Academia, Praha, 49-115.

GOJDA, M., JOHN, J. 2013: Archeologie a letecké laserové skenováni krajiny. Katedra archeologie, Západočeská univerzita v Plzni, Plzeň.

GRADY, D. M., 2000: Aerial reconnaissance in England: Some thoughts for the future. AARGnews. The Newsletter of the Aerial Archaeology Research Group 20, 15-26.

HAIGH, J. G. B. 1995: The current development of the AERIAL program. In: Kunow, J. (Ed.): Luftbildarchäologie in Ost- und Mitteleuropa. Brandenburgisches Landesmuseum für Ur- und Frühgeschichte. Potsdam, 149-154.

HAMPTON, J. N. 1978: The mapping and analysis of archaeological evidence provided by air photographs. Aerial Archaeology 2, 18-24.

HEIPKE, C., 1997: Automation of interior, relative, and absolute orientation. ISPRS Journal of Photogrammetry and Remote Sensing 52, 1-19.

HEIPKE, C., JACOBSEN, K., MILLS, J. 2006: Theme issue: "Digital aerial cameras". ISPRS Journal of Photogrammetry and Remote Sensing 60, 361-362.

KUNA, M. 1994: Archeologický priozkum povrchovými sběry. Zprávy České archeologické společnosti, Supplement 23, Praha.

KUNA, M. 1998: Keramika, povrchový sběr a kontinuita pravěké krajiny. Archeologické rozhledy 50, 192-223.

KUNA, M. 2000: Surface artefact studies in the Czech Republic. In: Bintliff, J. L., Kuna, M., Venclová, N. (Eds.): The Future of Surface Artefact Survey in Europe. Sheffield Academic Press, Sheffield, 29-44.

KUNA, M. 2004: Nedestruktivní archeologie. Academia, Praha.

LAMBERS, K., EISENBEISS, H., SAUERBIER, M., KUPFERSCHMIDT, D., GAISECKER, T., SOTOODEH, S., HANUSCH, T. 2007: Combining photogrammetry and laser scanning for the recording and modelling of the Late Intermediate Period site of Pinchango Alto, Palpa, Peru. Journal of Archaeological Science 34, 1702-1712.

LECKEBUSCH, J. 2005: Aerial archaeology: A full digital workflow for aerial photography. Archaeological Prospection 12, 235-244.

LEIDORF, K. 1996. Luftbildarchäologie - Geschichte und Methode. In: Becker, H. (Ed.): Archäologische Prospektion. Luftbildarchäologie und Geophysik. München, 33-44.
LILLESAND, T. M., KIEFER, R. W., CHIPMAN, J. W. 2015: Remote Sensing and Image Interpretation. 7th ed. John Wiley \& Sons, Hoboken, N.J.

MUSSON, C. 1995: Establishing a flying programme. In: Kunow, J. (Ed.): Luftbildarchäologie in Ost- und Mitteleuropa. Brandenburgisches Landesmuseum für Ur- und Frühgeschichte. Potsdam, 61-64.

NAGY, P., SCHLENTHER, U. 2007: The "AeroDat" project: $21^{\text {st }}$ century archaeological aerial survey. AARGnews. The Newsletter of the Aerial Archaeology Research Group 34, 14-27.

NEUSTUPNÝ, E. 1998: Space in Prehistoric Bohemia. Institute of Archaeology, Praha.

NEUSTUPNÝ, E., VENCLOVÁ, N. 2000: Surface artefact studies in the Czech Republic. In: Bintliff, J. L., Kuna, M., Venclová, N. (Eds.): The Future of Surface Artefact Survey in Europe. Sheffield Academic Press, Sheffield, 93-104.

OWEN, G. 2006: Digital jottings. AARGnews. The Newsletter of the Aerial Archaeology Research Group 32, 12-16.

PALMER, R. 2005: "If they used their own photographs they wouldn't take them like that". In: Brophy, K., Cowley, D. (Eds.): From the Air: Understanding Aerial Archaeology. Tempus, 94-116.

PAVELKA, K. 1999: Zpracování obrazových záznamů DPZ. $1^{\text {st }}$ ed., ČVUT, Stavební fakulta, Praha.

RACCZKOWSKI, W. 2004: Dusty treasure: thoughts on a visit to the Aerial Reconnaissance Archives at Keele University (UK). AARGnews. The Newsletter of the Aerial Archaeology Research Group 29, 9-11.

REDMAN, C. L. 1987: Surface collection, sampling, and research design: A retrospective. American Antiquity 52, 249-265.

RILEY, D. N. 1979: Factors in the development of crop marks. Aerial Archaeology 4, 28-32.

RISBØL, O., BRIESE, C., DONEUS, M., NESBAKKEN, A. 2015: Monitoring cultural heritage by comparing DEMs derived from historical aerial photographs and airborne laser scanning. Journal of Cultural Heritage 16, 202-209.

SCHENK, T. 2004: From point-based to feature-based aerial triangulation. ISPRS Journal of Photogrammetry and Remote Sensing, 58/5-6, 315-329.

SCHIFFER, M. B., SULLIVAN, A. P., KLINGER, T. C. 1978: The design of archaeological surveys. World Archaeology 10, 1-28.

SCOLLAR, I. 1998: AirPhoto - A WinNT/Win95 program for geometric processing of archaeological air photos. AARGnews. The Newsletter of the Aerial Archaeology Research Group 16, 37-38.

SCOLlAR, I., TABBAGH, A., HESSE, A., HERZOG, I. 1990: Archaeological Prospecting and Remote Sensing. Cambridge University Press, Cambridge.

SMRŽ, Z., KUNA, M., KÁČERIK, A., 2011: Archeologie mizející krajiny. Terénní průzkum předpolí Dolů Nástup Tušimice. Památky archeologické $102,159-216$.

STANJEK, H., FAßBINDER, J. 1996: Bodenkundliche Untersuchungen zum Verständnis archäologischer Strukturen im Luftbild. In: Becker, H. (Ed.): Archäologische Prospektion. Luftbildarchäologie und Geophysik. München, 249-255.

ŠMEJDA, L. 2003: Možnosti využití techniky „Multi-Criteria Evaluation“ v prostorové archeologii. In: Neustupný, E. (Ed.): Přrispěvky k prostorové archeologii 1. Katedra archeologie FHS ZČU, Plzeň, 230-246.

ŠMEJDA, L. 2009: Mapováni archeologického potenciálu pomocí leteckých snímkủ. Západočeská univerzita v Plzni, Plzeň.

TRIER, Ø. D., ZORTEA, M., TONNING, C. 2015: Automatic detection of mound structures in airborne laser scanning data. Journal of Archaeological Science: Reports 2, 69-79.

VERHOEVEN, G. 2007. Did the digital (r)evolution change the concept of focal length? AARGnews. The Newsletter of the Aerial Archaeology Research Group 34, 30-35. 